\title{
Relevant approach to assess the performance of sawdust as adsorbent of chromium (VI) ions from aqueous solutions
}

\author{
V. Vinodhini; *N. Das \\ Environmental Biotechnology Division, School of Biosciences and Technology, VIT University, Vellore-632014, \\ Tamil Nadu, India \\ Received 10 July 2009; $\quad$ revised 5 October 2009; accepted 3 November 2009; available online 1 December 2009
}

\begin{abstract}
The biosorption of chromium (VI) ions from aqueous solutions by two adsorbents viz. mango and neem sawdust was studied under a batch mode. An initial $\mathrm{pH}$ of 2.0 was most favorable for chromium (VI) removal by both the adsorbents. The results obtained for the final concentration of chromium (VI) and chromium (III) at a $\mathrm{pH}$ range of 2-8 indicated that a combined effect of biosorption and reduction was involved in the chromium (VI) removal specially when the $\mathrm{pH}$ value is lower than 3 . The maximum loading capacity was calculated from adsorption isotherms by applying the Langmuir model and found to be higher for neem sawdust (58.82 mg/g). Evaluation of experimental data in terms of biosorption kinetics showed that the biosorption of chromium (VI) by neem sawdust followed pseudo second-order kinetics. Therefore, the rate limiting step may be chemical sorption or chemisorption. The efficiency of this process was examined in using tannery wastewater contaminated with chromium (VI) ions in column mode.
\end{abstract}

Keywords: Biosorbent; Biosorption; Desorption; Isotherm models; Kinetics; Wastewater

\section{INTRODUCTION}

Environmental contamination by toxic metals is of great concern because of health risks on humans and animals. Among the toxic metal ions, chromium is one of the common contaminants which gains importance due to its high toxic nature even at very low concentrations (Shrestha et al., 2007; Mahvi, 2008).

Chromium (VI) is a cancer-causing agent and can pose health risks such as liver damage, dermatitis and gastrointestinal ulcers (Dokken et al., 1999). Wastewaters such as those generated during dyes and pigments production, film and photography, galvanometry, metal cleaning, plating and electroplating, leather and mining may contain undesirable amounts of chromium (VI) anions (Loukidou et al., 2004, Venkateswaran et al., 2007; Bhattacharya et al., 2008).

The conventional methods used to remove $\mathrm{Cr}$ (VI) from aqueous effluents include chemical reduction, nanofiltration, bioaccumulation, ion-exchange, adsorption on silica composites and on activated carbon. However, these approaches have proved to be costlier and difficult to implement. Biosorption, a technically feasible and economical process, has gained increased credibility during recent years (Loukidou et al., 2004).

凶*Corresponding Author Email: nilanjana00@lycos.com

Tel.: +91416 2202 478; Fax: +91416 2243092
Though a number of reports have appeared on the removal of chromium (VI) ions from aqueous solutions using inexpensive bio-waste materials (Dakiky et al., 2002; Amir et al., 2005; Ahalya et al., 2005; Babel and Opiso, 2007; Nameni et al., 2008; Wang et al., 2008; Shah et al., 2009; Zvinowanda et al., 2009), new economical, easily available and highly effective adsorbents are still needed. Sawdust is a widely available waste by-product of the timber industry that is either used as cooking fuel or a packing material. Some reports using treated sawdust for removal of chromium (VI) ions are available (Garg et al., 2004; Baral et al., 2006), but information on raw sawdust is limited. The neem tree (Azadirachta indica) of family Meliaceae is native to the Indian sub-continent and its seeds and leaves have been used traditionally to treat a number of human ailments and also as a household pesticide. The tree itself is known as an air purifier and different parts of the tree such as leaves, bark, and seeds have been reported to possess a variety of medicinal and germicidal properties (Chopra et al., 1956). The aim of the present investigation is to detect the performance of raw neem sawdust and mango sawdust on chromium (VI) removal from aqueous solutions by varying chromium (VI) concentration, $\mathrm{pH}$ and contact time. Adsorption 
isotherms and kinetic models were applied to fit the experimental data. The effectiveness of desorbing agent $(\mathrm{NaOH})$ in stripping adsorbed metal ions from biosorbent was also investigated.

\section{MATERIALS AND METHODS}

All the chemicals used in this study were of analytical grade and were procured from sd-fine chem. Ltd. The adsorbents selected for the study viz. neem sawdust and mango sawdust were collected from the saw mill. These adsorbents were washed with deionized water and dried at room temperature $\left(28 \pm 2^{\circ} \mathrm{C}\right)$ till a constant weight of the adsorbent was achieved. The stock solution of chromium (VI) (1000 mg/L) was prepared by dissolving $2.829 \mathrm{~g}$ of potassium dichromate $\left(\mathrm{K}_{2} \mathrm{Cr}_{2} \mathrm{O}_{7}\right)$ in $1000 \mathrm{~mL}$ of deionised water. Experimental solutions of the desired concentrations were obtained by successive dilutions. The $\mathrm{pH}$ of the solution was adjusted with $0.1 \mathrm{~N} \mathrm{HNO}_{3}$ and $\mathrm{NaOH}$ solutions. Batch sorption experiments were conducted in $250 \mathrm{~mL}$ Erlenmeyer flasks containing $100 \mathrm{~mL}$ of chromium (VI) solution of known concentration and $\mathrm{pH}$ value. These metal solutions containing the biosorbent dosage of $2 \mathrm{~g} / \mathrm{L}$ were agitated in a rotary shaker at $120 \mathrm{rpm}$ for a desired time. The samples were withdrawn from the shaker at the predetermined time intervals and adsorbent was separated by filtration. Chromium (VI) concentration in the filtrate was estimated using UV spectrophotometer at $540 \mathrm{~nm}$ wavelength by 1, 5- diphenyl carbazide method (APHA, 1998). The experiments were carried out by varying the chromium (VI) concentration in the solution (10-150 $\mathrm{mg} / \mathrm{L}), \mathrm{pH}(2.0-8.0)$ and contact time (5-360 $\mathrm{min})$. The kinetic studies were performed by varying the biomass dosage form 1 to $3 \mathrm{~g} / \mathrm{L}$ with initial metal concentration of $100 \mathrm{mg} / \mathrm{L}$ at room temperature $28 \pm 2{ }^{\circ} \mathrm{C}$ and solution $\mathrm{pH}$ (2.0). The samples were collected at different time intervals ( $5 \mathrm{~min}$ to $6 \mathrm{~h}$ ) and the biosorbent was separated by filtration and supernatant analyzed for residual chromium (VI) concentrations. To study the reduction rate of chromium (VI) to chromium (III) by neem sawdust, the effect of $\mathrm{pH}(2-8)$ was studied in batch mode with an adsorbent dosage of $2 \mathrm{~g} / \mathrm{L}$ at room temperature (28 \pm 2 ${ }^{\circ} \mathrm{C}$ ) on a rotary shaker at $120 \mathrm{rpm}$. Total chromium was estimated by atomic absorption spectrophotometer (Spectra AA, Varian Model) using air-acetylene flame at $429 \mathrm{~nm}$ wavelength and slit width of $0.5 \mathrm{~nm}$ chromium (VI) concentration was estimated using UV spectrophotometer at $540 \mathrm{~nm}$ wavelength by 1, 5diphenyl carbazide method (APHA 1998). chromium (III) concentration of the sample was calculated as difference of total chromium and chromium (VI) for the same sample solution. The uptake of chromium (VI) by neem sawdust was studied in the presence of other anions $\left(\mathrm{SO}^{2-}, \mathrm{PO}_{4}^{3}\right.$, $\mathrm{NO}^{3-}$ and $\left.\mathrm{Cl}^{-}\right)$and cations $\left(\mathrm{Na}^{+}, \mathrm{K}^{+}, \mathrm{Mg}^{2+}\right.$ and $\left.\mathrm{Ca}^{2+}\right)$.

The raw tannery wastewater sample collected from a common effluent treatment plant (CETP) located in Vaniyambadi, Vellore Dt., Tamil Nadu, India was analyzed promptly for determining the physicochemical characteristics using standard analytical methods (APHA, 1998). The characteristics of the wastewater were: color: black, pH: 6.1, TDS: 7794 mg/L, TSS: 4896 mg/L, sulphates: $878 \mathrm{mg} / \mathrm{L}$, chlorides: $2927 \mathrm{mg} / \mathrm{L}$ and nitrate: $9.8 \mathrm{mg} / \mathrm{L}$. The concentration of chromium (VI) in wastewater was detected using UV spectrophotometer: $94 \mathrm{mg} / \mathrm{L}$ and $\mathrm{pH}$ was adjusted to 2.0 using $0.1 \mathrm{~N} \mathrm{HNO}_{3}$. The wastewater was then fed through a glass column (3 $\mathrm{cm}$ i.d. and $10 \mathrm{~cm}$ long) packed with $20 \mathrm{~g}$ of the biosorbent neem sawdust at a flow rate of $5.0 \mathrm{~mL} / \mathrm{min}$ controlled by a peristaltic pump. After treatment, the samples collected from the exit were analyzed for chromium (VI) concentrations. The wastewater was treated till the values reached to satisfy the Central Pollution Control Board(CPCB) standards (Cr (VI) - 0.1 mg/L) (CPCB, 1998).

\section{RESULTS AND DISCUSSION}

\section{Effect of $p H$ on sorption}

Earlier studies on heavy metal biosorption have shown that solution $\mathrm{pH}$ is the single most important parameter affecting the biosorption process (Chen et al., 2002). In order to establish the effect of $\mathrm{pH}$ on the biosorption of chromium (VI) ions, batch sorption studies at different $\mathrm{pH}$ values were conducted in the range of 2.0 to 8.0. Fig. 1 reveals that biosorption capacity of $\mathrm{Cr}$ (VI) ions is maximum at $\mathrm{pH} 2.0$ and significantly decreases with increase in $\mathrm{pH}$ values upto 8.0. At $\mathrm{pH} 2$ and 8 corresponding uptake yield values were found to be $80.1 \%$ and $7.6 \%$ for neem sawdust, $60 \%$ and $6.3 \%$ for mango sawdust, respectively.

At lower $\mathrm{pH}$, the biosorbent is positively charged due to protonation and dichromate ion exists as anion leading to an electrostatic attraction between them (Boddu et al., 2003). Thus the uptake of chromium (VI) increased markedly with decreasing $\mathrm{pH}$. A sharp decrease in adsorption above $\mathrm{pH} 4$ may be due to occupation of the adsorption sites by anionic species like $\mathrm{HCrO}_{4}^{--} ; \mathrm{Cr}_{2} \mathrm{O}_{7}^{2-} ; \mathrm{CrO}_{4}^{2-}$; etc. which retards the approach of such ions further towards the sorbent surface (Das et al., 2000; Donmez and Aksu, 2002). Popuri et al. (2007) has reported that the decrease in adsorption at high $\mathrm{pH}$ values may be due to the competitiveness 
of the oxyanion of chromium and $\mathrm{OH}^{-}$ions in the bulk. These results suggest that $\mathrm{pH}$ affects the solubility of metals and the ionization state of the functional groups like carboxylate, phosphate and amino groups of the cell walls of the biosorbent.

\section{Adsorption isotherm}

Adsorption isotherms are basic requirements for designing any adsorption system. Isotherm expresses the relation between the amounts of adsorbate (mg) removed from the liquid-phase by unit of mass of biosorbent (g) at fixed temperature (Freundlich, 1906; Langmuir, 1918; Redlich and Peterson, 1959; Sips, 1959). The Langmuir and Freundlich isotherm model were used to describe the biosorption equilibrium of biomass. The Freundlich isotherm is a nonlinear sorption model. This model proposes a monolayer sorption with a heterogeneous energetic distribution of active sites, accompanied by interactions between adsorbed molecules. The general form of this model is:

$q_{e}=\mathrm{K}_{\mathrm{f}} \mathrm{C}^{1 /}$

Where, $\mathrm{K}_{\mathrm{f}}(\mathrm{mg} / \mathrm{g})$ stands for adsorption capacity and $n$ for adsorption intensity.

The logarithmic form of Eq. 1 is:

$\log q_{e}=\log K_{f}+1 / n \log C_{e}$

The Langmuir model represents one of the first theoretical treatments of nonlinear sorption and suggests that uptake occurs on a homogeneous surface by monolayer sorption without interaction between adsorbed molecules. In addition, the model assumes uniform energies of adsorption onto the surface and no transmigration of the adsorbate.

The Langmuir isotherm is represented in the following equation:

$$
q_{e}=\frac{q_{\max } b C_{e}}{1+b C_{e}}
$$

Where, $q_{\max }(\mathrm{mg} / \mathrm{g})$ and $b$ are Langmuir constants related to adsorption capacity and the energy of biosorption, respectively.

Experimental adsorption isotherms of chromium ions, obtained with different initial metal ion concentrations are presented in Figs. 2 and 3 which indicate the linear relationship between the amounts (mg) of chromium (VI) ions sorbed per unit mass (g) of the biosorbent against the concentration of chromium (VI) ions remaining in solution (mg/L). The values of regression coefficients obtained from these models were used as the fitting criteria to find out these isotherms. It was observed that the experimental data fits well to Langmuir adsorption isotherm indicating both monolayer biosorption and heterogenous surface conditions. The adsorption capacities and values of regression coefficients are shown in Table 1. Based on the $\mathrm{q}_{\max }$ values, it can be noteworthy that neem sawdust has maximum potential for the removal of chromium (VI) ions from aqueous solution.

The experimental conditions i.e adsorption capacity, $\mathrm{pH}$ and initial metal ion concentration $\left(\mathrm{C}_{\mathrm{o}}\right)$ values for the biosorption of chromium (VI) ions on different sawdust have been shown in Table 2. Compared to the reported ones, the biosorption capacity of neem sawdust for

Table 1: Linear regression data for angmuir and Freundlich isotherms for chromium (VI) biosorption

\begin{tabular}{llllllllr}
\hline \multirow{2}{*}{ Biosorbents } & \multicolumn{3}{c}{ Langmuir parameters } & \multicolumn{3}{c}{ Freundlich parameters } \\
& \multicolumn{2}{c}{$\mathrm{q}_{\max }$} & $\mathrm{b}$ & $\mathrm{R}^{2}$ & $\mathrm{~N}$ & $\mathrm{~K}_{\mathrm{f}}$ & $\mathrm{R}^{2}$ & \\
\hline Neem sawdust & $(\mathrm{mg} / \mathrm{g})$ & $(\mathrm{L} / \mathrm{mg})$ & & 2.1659 & 8.3926 & 0.739 \\
Mango sawdust & 58.82 & 13.68 & 0.9809 & 2.5967 & 7.1779 & 0.8782 \\
\hline
\end{tabular}

Table 2: Comparison of adsorption capacities of different types of sawdust reported in literature

\begin{tabular}{|c|c|c|c|c|}
\hline Adsorbents & $\begin{array}{c}\text { Adsorption } \\
\text { capacity mg/g }\end{array}$ & $\mathrm{pH}$ & $\mathrm{C}_{0} \mathrm{mg} / \mathrm{L}$ & References \\
\hline Coconut tree sawdust & 3.60 & 3 & 20 & Selvi et al., 2001 \\
\hline Beech sawdust & 16.10 & 1 & 200 & Acar and Malkoc, 2004 \\
\hline Treated sawdust of Indian Rosewood & 10.00 & 3 & 100 & Garg et al. 2004 \\
\hline Hevea brasiliensis sawdust activated carbon & 44.05 & 2 & 200 & Karthikeyan et al., 2005 \\
\hline Treated sawdust of Sal tree & 9.55 & 3.5 & 40 & Baral et al., 2006 \\
\hline Neem sawdust & 58.82 & 2 & 150 & Present study \\
\hline Mango sawdust & 37.73 & 2 & 150 & Present study \\
\hline
\end{tabular}


chromium (VI) is higher than the majority of the sawdust (treated or untreated). Since mango sawdust showed less potentiality compared to neem sawdust, further studies were carried out using neem sawdust as adsorbent.

\section{Sorption kinetics}

The kinetics of metal ion sorption is an important parameter for designing sorption systems. In addition to the uptake capacity, the rate of uptake of the adsorbate by the biosorbent is also critical as far as the reactor configuration is concerned. Arapid kinetics will facilitate smaller reactors (lower retention time for effective metal uptake) whereas a slow rate of uptake will necessitate long column or series of columns to utilize maximum potential of the biosorbent. The rate of sorption onto a sorbent surface depends upon a number of parameters such as structural properties of the sorbent, initial concentration of the solute and the interaction between the solute and the active sites of the sorbent (Oliveira et al., 2005). The effect of external film diffusion on biosorption rate is assumed to be insignificant and ignored in many kinetic analyses, particularly when the biosorbent is employed as a free suspension in a well agitated batch system. Rate of adsorption is usually measured by determining the change in concentration of the adsorbate in contact with the adsorbent as a function of time. The kinetics of chromium (VI) sorption on the biosorbent neem sawdust was analyzed using two simple kinetic models viz. the pseudo-first order (Lagergren, 1898) and pseudo-second order (Ho and Mckay, 1999).

\section{Pseudo first-order model}

The adsorption kinetic data of chromium (VI) adsorption were analyzed using Lagergren rate equation (Lagergren, 1898) which considers that the rate of occupation of biosorption sites is proportional to the number of unoccupied sites (Cruz et al., 2004). $\frac{d q_{t}}{d_{t}}=k_{1}\left(q_{e}-q_{t}\right)$

Integrating Eq. 2 between limits, $q_{t}=0$ at $\mathrm{t}=0$ and $q_{t}=$ $\mathrm{q}_{\mathrm{t}}$ at $\mathrm{t}=\mathrm{t}$, Eq. 4 is obtained.

$\log \frac{q_{e}}{q_{e}-q_{t}}=\frac{k}{2.303} t$

Eq. 5 can be rearranged to obtain a linear form:

$\log \left(q_{e}-q_{t}\right)=\log q_{e}-\frac{k 1}{2.303} t$

Where, $q_{\mathrm{e}}$ and $q_{t}$ are the amounts of adsorbed chromium (VI) ions on the biosorbent at equilibrium and at time $t(\mathrm{mg} / \mathrm{g})$, respectively and $k_{1}$ is the equilibrium rate constant of pseudo-first-order adsorption. The slope and intercept of the plot, $\log \left(q_{\mathrm{e}}\right.$ - $q_{t}$ ) versus $t$ were used to obtain the first-order rate constant $k_{1}$ and equilibrium adsorption density $q_{\mathrm{e}}$ (Fig. 4). Lagergren first-order rate constant $k_{1}$ and $q_{e}$ determined from the model indicated that this model had failed to estimate $\mathrm{q}_{\mathrm{e}}$ since the experimental values of $q_{e}$ differs from estimated ones (Table 3 ). This shows that the adsorption of chromium (VI) onto neem sawdust was not appropriate to describe the entire process and not a first-order reaction.

\section{Pseudo second-order model}

The sorption data were analyzed according to the pseudo second-order kinetic model (Ho and Mckay, 1998). This kinetic model is based on the assumption that the biosorption process follows a second order mechanism, with chemisorption as the rate limiting step. Therefore, the occupation rate of adsorption sites is proportional to the square of the number of unoccupied sites (Antunes et al., 2003) and can be expressed as follows:

$\frac{t}{q_{t}}=\frac{1}{k_{2}\left(q_{e}\right)^{2}}+\frac{t}{q_{e}}$

Table 3: Adsorption first-order and second-order kinetic model rate constants of neem sawdust for biosorption of chromium (VI) for various biosorbent dosages

\begin{tabular}{|c|c|c|c|c|c|c|c|}
\hline \multirow{2}{*}{$\begin{array}{l}\text { Biosorbent } \\
\text { dosage } \\
(\mathrm{mg} / \mathrm{L})\end{array}$} & \multirow[b]{2}{*}{$\begin{array}{c}q_{\text {eexp }} \\
(\mathrm{mg} / \mathrm{g})\end{array}$} & \multicolumn{3}{|c|}{ First-order kinetic model } & \multicolumn{3}{|c|}{ Second-order kinetic model } \\
\hline & & $\begin{array}{l}\mathrm{K}_{1} \\
(\mathrm{~L} / \mathrm{min})\end{array}$ & $\begin{array}{c}q_{e \mathrm{cal}} \\
(\mathrm{mg} / \mathrm{g})\end{array}$ & $\mathrm{R}^{2}$ & $\begin{array}{l}\mathrm{K}_{2} \\
(\mathrm{~L} / \mathrm{min})\end{array}$ & $\begin{array}{l}q_{e \mathrm{cal}} \\
(\mathrm{mg} / \mathrm{g})\end{array}$ & $\mathrm{R}^{2}$ \\
\hline 1 & 74.7 & 0.023 & 32.56 & 0.9682 & 0.0884 & 75.1 & 0.9877 \\
\hline 2 & 40.1 & 0.060 & 23.47 & 0.9709 & 0.1379 & 40.0 & 0.9805 \\
\hline 3 & 28.4 & 0.076 & 22.70 & 0.9002 & 0.1074 & 29.9 & 0.9701 \\
\hline
\end{tabular}

(Initial metal concentration- $100 \mathrm{mg} / \mathrm{L}, \mathrm{pH}-2$, temp. $28 \pm 1^{\circ} \mathrm{C}$, agitating rate-120 rpm) 


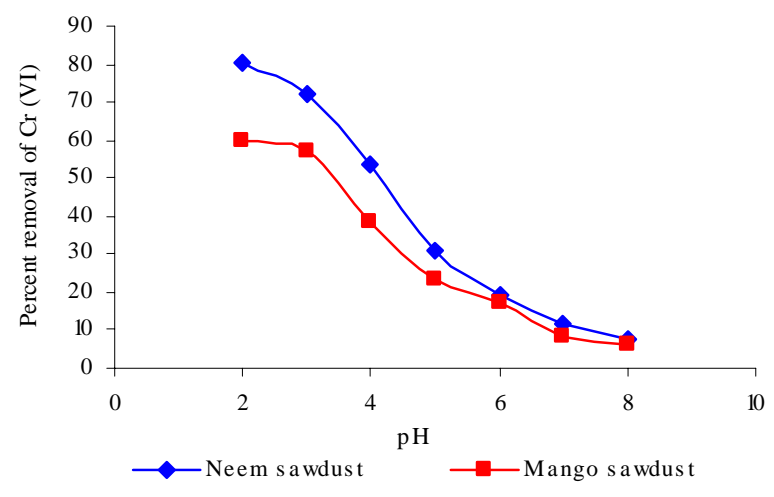

Fig. 1: Effect of $\mathrm{pH}$ on biosorption of $\mathrm{Cr}$ (VI) biosorbent dosage: $2 \mathrm{~g} / \mathrm{L}$, Initial metal concentration: $100 \mathrm{mg} / \mathrm{L}$, contact time: $2 \mathrm{~h}$

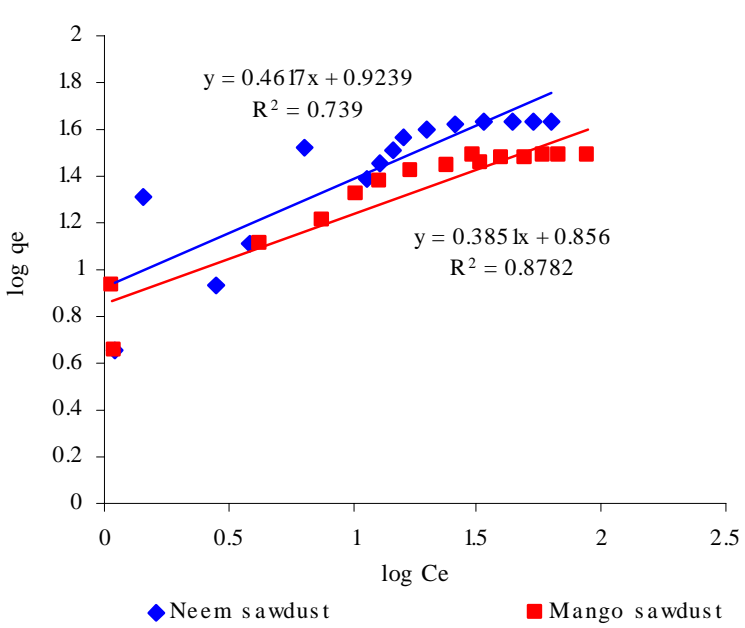

Fig. 3: Freundlich adsorption isotherms for Cr (VI)

Where, $k_{2}$ is pseudo-second order rate constant. After integration and applying the same boundary conditions $t=0$ and $\mathrm{q}_{\mathrm{t}}=0$ to $t=t$ and $\mathrm{q}_{t}=\mathrm{q}_{\mathrm{e}}$ at equilibrium, Eq. 7 takes the following form:

$\frac{d q}{d t}=k_{2}\left(q_{e}-q_{t}\right)^{2}$

The second order rate constant $k_{2}$ and $q_{\mathrm{e}}$ values were determined from the slopes and intercepts of the plots and are presented in Fig. 5. The correlation coefficients $\left(\mathrm{R}^{2}\right)$ also shown in Table 3, are indicative of the strength of the linear relationship. The theoretical $q_{\mathrm{e}}$ values (i.e. $q_{e, \text { cal }}$ ) agree well with the experimental $q_{\mathrm{e}}$ values (i.e. $\left.q_{e \text { exp }}\right)$, suggesting the sorption data tend to follow second order kinetics for chromium (VI) sorption onto neem sawdust. Therefore, the rate limiting step may be

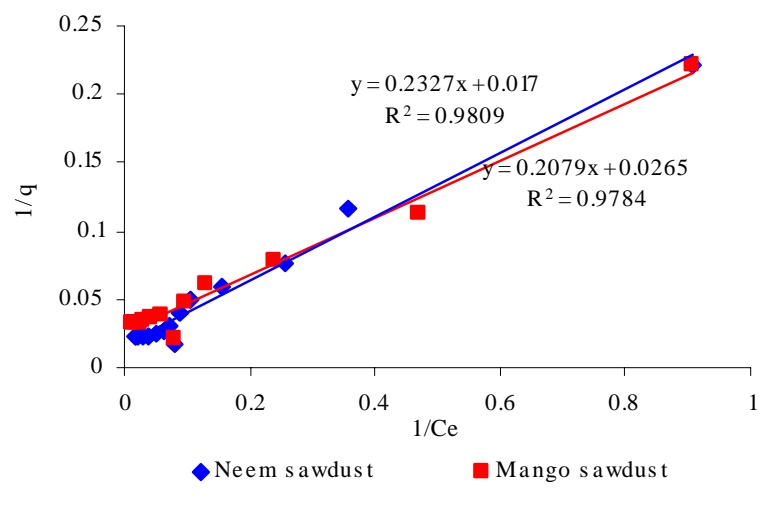

Fig. 2: Langmuir adsorption isotherms for Cr (VI)

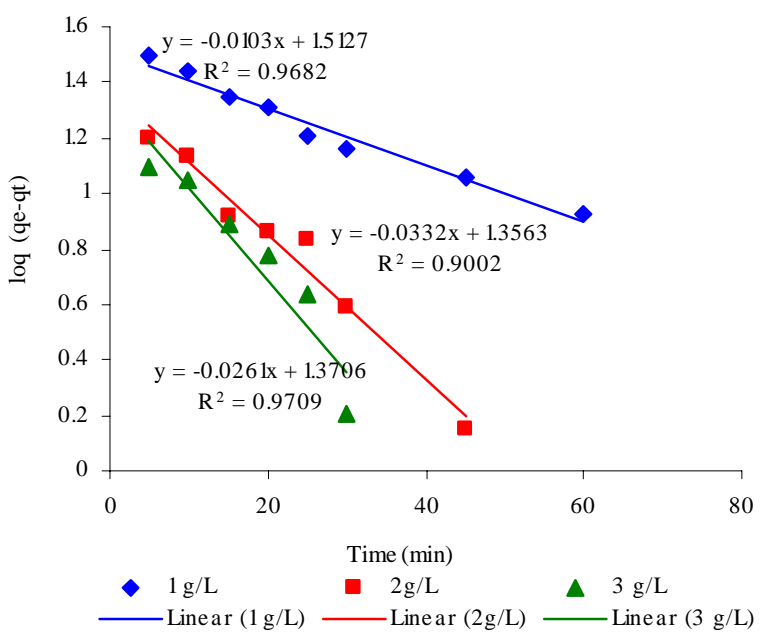

Fig. 4: Plot of the pseudo-first order kinetics of Cr (VI) for various biosorbent dosages

chemical sorption or chemisorption. Similar results have been observed in the adsorption of chromium (VI) onto used tyres and sawdust (Hamadi et al., 2001) and activated carbons derived from agricultural waste materials (Mohan et al., 2005).

Reduction of Cr (VI) to Cr (III) by neem sawdust

Experiments were carried out to verify the mechanism of chromium (VI) biosorption on neem sawdust by varying the $\mathrm{pH}$ from 2-8. The final concentrations of the total chromium, chromium (VI) and chromium (III) in a pH range of 2-8 were analyzed. The percent removal of chromium (VI) and reduction to chromium (III) as a function of $\mathrm{pH}$ is shown in Table. 4 The results indicated that in acidic $\mathrm{pH}$ a combined effect of $\mathrm{Cr}$ (VI) biosorption and reduction to $\mathrm{Cr}$ (III) was found. The chromium (VI) 


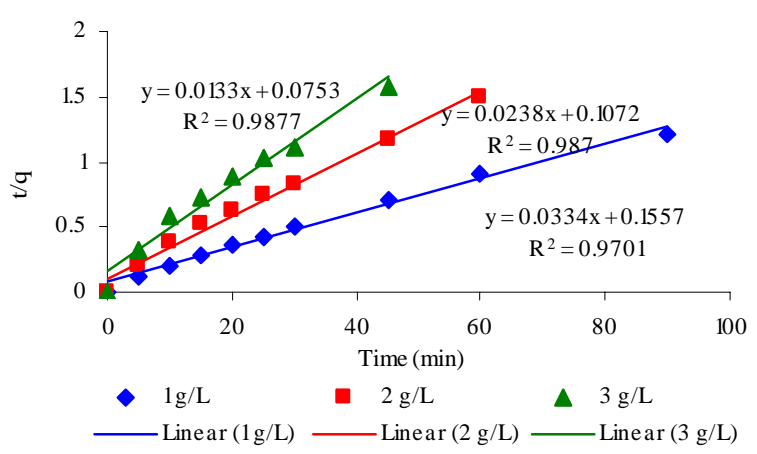

Fig. 5: Plot of the pseudo-Second order Kinetics of Cr (VI) for variousbiosorbent dosages

Table 4: Removal and reduction efficiency of chromium (VI) at different $\mathrm{pH}$

\begin{tabular}{lcc}
\hline $\mathrm{pH}$ & $\begin{array}{c}\text { \% Removal } \\
\text { of chromium (VI) }\end{array}$ & $\begin{array}{c}\text { \% Reduction } \\
\text { to chromium (III) }\end{array}$ \\
\hline 2 & 80.11 & 15.3 \\
3 & 71.9 & 11.9 \\
4 & 53.8 & 7.4 \\
5 & 30.8 & 0.6 \\
6 & 19.2 & 0 \\
7 & 11.4 & 0 \\
8 & 7.6 & 0 \\
\hline
\end{tabular}

was reduced to chromium (III) when contacted with neem sawdust in acidic $\mathrm{pH}$. As the $\mathrm{pH}$ increases the percent removal of chromium (VI) and reduction to chromium (III) reduced gradually, thus, the mechanism involved in biosorption of chromium (VI) may be adsorption coupled reduction. However, further studies need to be carried out to understand the actual mechanism involved in the adsorption of chromium (VI) onto neem sawdust.

\section{Effect of co-ions}

Actual industrial wastewaters contain different kinds of co-ions i.e cations $\left(\mathrm{Na}^{+}, \mathrm{K}^{+}, \mathrm{Mg}^{2+}\right.$ and $\left.\mathrm{Ca}^{2+}\right)$ and anions $\left(\mathrm{SO}_{4}^{2-}, \mathrm{PO}_{4}^{3-}, \mathrm{NO}^{-3}\right.$ and $\left.\mathrm{Cl}^{-}\right)$which may interfere with the uptake of chromium (VI) ions during biosorption. Hence, in the present investigation, the effect of different cations and anions on chromium (VI) biosorption by neem sawdust was studied. It was found that, under the conditions used, the influence of cations such as $\mathrm{Na}^{+}$, $\mathrm{K}^{+}, \mathrm{Mg}^{2+}$ and $\mathrm{Ca}^{2+}$ did not interfere much with adsorption of chromium (VI) whereas anions like $\mathrm{SO}_{4}^{2-}, \mathrm{PO}_{4}^{3-}, \mathrm{NO}^{3-}$ and $\mathrm{Cl}^{-}$influenced the removal of chromium (VI) significantly (Table 5). This shows that the above anions competed for the adsorption sites with chromium (VI)

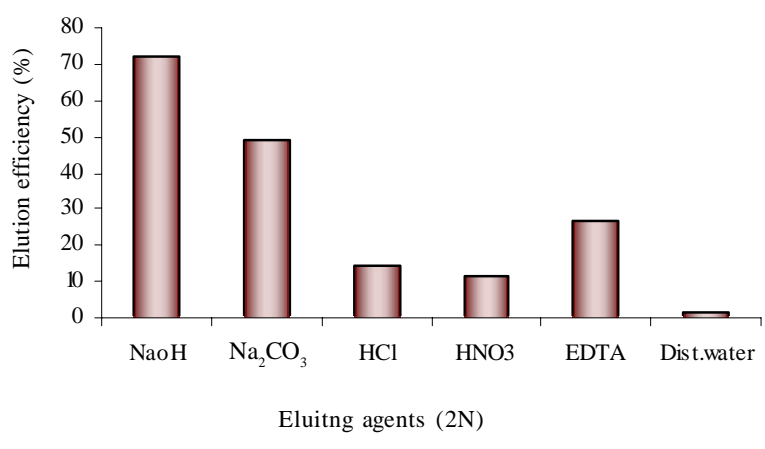

Fig. 6: Desorption of Cr (VI) by different desorbing agent

Table 5: Effect of co-ions on biosorption of chromium (VI) onto neem sawdust

\begin{tabular}{lcc}
\hline Co-ions added & $\begin{array}{c}\text { Concentration of } \\
\text { co -ions }(\mathrm{mg} / \mathrm{L})\end{array}$ & $\begin{array}{c}\text { Percent uptake of } \\
\mathrm{Cr}(\mathrm{VI})\end{array}$ \\
\hline $\mathrm{Cr}(\mathrm{VI})$ alone & - & 81.70 \\
Cations & & \\
$\mathrm{Cr}(\mathrm{VI})+\mathrm{Na}^{+}$ & 1250 & 78.80 \\
$\mathrm{Cr}(\mathrm{VI})+\mathrm{K}^{+}$ & 1250 & 79.65 \\
$\mathrm{Cr}(\mathrm{VI})+\mathrm{Mg}^{2}$ & 1250 & 79.50 \\
$\mathrm{Cr}(\mathrm{VI})+\mathrm{Ca}^{2+}$ & 1250 & 78.70 \\
& & \\
$\mathrm{Anions}$ & & 65.10 \\
$\mathrm{Cr}(\mathrm{VI})+\mathrm{SO}^{2-}$ & 1250 & 70.60 \\
$\mathrm{Cr}(\mathrm{VI})+\mathrm{PO}^{3-}{ }_{4}$ & 1250 & 68.10 \\
$\mathrm{Cr}(\mathrm{VI})+\mathrm{NO}^{-3}$ & 1250 & 62.90 \\
$\mathrm{Cr}(\mathrm{VI})+\mathrm{Cl}^{-}$ & 1250 & \\
& & \\
\hline
\end{tabular}

species and hence, there were no specific or exclusive sites for chromium (VI) adsoption on the surface of the sorbent.

\section{Desorption and reuse}

Regeneration of biosorbent for repeated reuse is of crucial importance in industrial practice for metal removal from wastewater. Experiments were conducted for regenerating sawdust using various desorbing agents $\left(\mathrm{HCl}, \mathrm{HNO}_{3}, \mathrm{NaOH}, \mathrm{Na}_{2} \mathrm{CO}_{3}\right.$ and EDTA). The elution efficiency of these desorbing agents is shown in Fig. 6. The results obtained indicated that desorption of chromium (VI) ions with acids was marginal. Maximum desorption was achieved using $\mathrm{NaOH}$ as desorbing agent.Experiments conducted with different concentrations of $\mathrm{NaOH}(0.5 \mathrm{~N}, 1 \mathrm{~N}, 2 \mathrm{~N})$ showed that the percent desorption of chromium (VI) increased with 


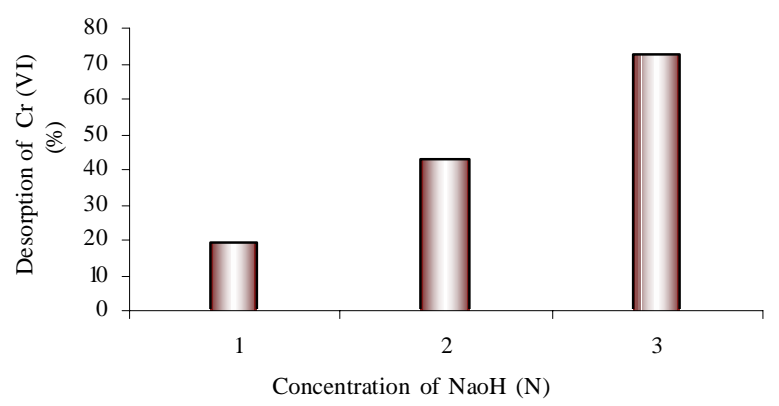

Fig. 7: Desorption of Cr (VI) using different concentrations of $\mathrm{NaOH}$

increase in concentration of the desorbing agent (Fig. 7). In order to show the reusability of the biosorbent, experiment on cyclic sorption of chromium was conducted. For the cyclic loading of chromium (VI), 0.2g of neem sawdust was contacted with $100 \mathrm{~mL}$ of chromium (VI) solution having concentration of $100 \mathrm{mg} / \mathrm{L}$ for $1 \mathrm{~h}$. The cycle was repeated for 4 times at $\mathrm{pH}-2$ and temperature $28 \pm 2^{\circ} \mathrm{C}$ followed by successive desorption after each biosorption cycle. At the end of every sorption cycle, metal solution was filtered and the metal concentration determined. The total amount of chromium (VI) sorbed on neem sawdust was 81.7\%, 76.4\%, 71.1\% and $65.6 \%$ after 1 st, 2nd, 3rd and 4th cycle, respectively. This observation indicates that neem sawdust was able to adsorb chromium (VI) ions even up to the 4th cycle, though the extent of metal sorption has gradually decreased. The results of the above experiments indicate the possibility of reusing the spent sorbent.

\section{Column experiments using tannery wastewater}

In order to demonstrate the practical application of the biosorption process, column experiment using neem sawdust was conducted with wastewater and the efficiency of the process was determined. The results showed that about $20 \mathrm{~g}$ of biosorbent was sufficient to treat a wastewater volume of $1.5 \mathrm{~L}$ containing chromium (VI) ions. The wastewater was treated till the chromium (VI) concentration reached the values established by (CPCB, 1998) (chromium (VI) - $0.1 \mathrm{mg} / \mathrm{L}$ ). Therefore, the present study confirmed that neem sawdust could serve as an economically viable potential biosorbent for the treatment of wastewater containing $\mathrm{Cr}$ (VI) ions.

\section{CONCLUSION}

This study identified neem sawdust as a suitable biosorbent for chromium (VI) removal in batch and column experiments. The adsorption process was $\mathrm{pH}$ dependent and the optimum pH was 2.0 for biosorption and reduction of chromium (VI). The probable mechanism of chromium (VI) adsorption may be adsorption coupled reduction. Adsorption isotherm data at various initial metal concentrations were in good agreement with the Langmuir isotherm. Second-order kinetics was found to explain the kinetics of chromium (VI) adsorption most effectively. Present research also confirmed the potentiality of neem sawdust for the removal of chromium (VI) ions from real wastewater using column mode.

\section{ACKNOWLEDGEMENTS}

The authors would like to express their gratitude and appreciation to VIT University, Vellore for providing technical support to carry out the research work.

\section{REFERENCES}

Acar, F. N.; Malkoc, E., (2004). The removal of chromium (VI) from aqueous solutions by Fagus orientalis L., Bioresour. Tech., 94 (1), 13-15 (3 pages).

Ahalya, N.; Kanamadi, R. D.; Ramachandra, T. V., (2005). Biosorption of chromium (VI) from aqueous solutions by the husk of Bengal gram (Cicer arientinum). Electron. J. Biotech., 8 (3), 258-264 (7 pages).

Amir, H. M.; Dariush, N.; Forugh, V.; Shahrokh, N., (2005). Teawaste as an adsorbent for heavy metal removal from industrial wastewaters., Am. J. Appl. Sci., 2 (1), 372-375 (4 pages).

Antunes, W. M.; Luna, A. S.; Henriques, C. A.; Costa, A. C. S., (2003). An evaluation of copper biosorption by a brown seaweed under optimized conditions. Electron. J. Biotech., 6 (3), 174-184 (11 pages).

APHA, (1998). Standard methods for examination of water and waterwaste. $20^{\text {th. }}$ Ed., American Public Health Association, Am. Water Works Association, Water Environ. Federation, Washington, D.C.

Babel, S.; Opiso, E. M., (2007). Removal of Cr from synthetic wastewater by sorption into volcanic ash soil. Int. J. Environ. Sci. Tech., 4 (1), 99-108 (10 pages).

Baral, S. S.; Surendra, N.; DasRath, P., (2006). Hexavalent chromium removal from aqueous solution by adsorption on treated sawdust. Biochem. Eng. J., 31 (3), 216-222 (7 pages).

Bhattacharya, A. K.; Naiya, T. K.; Mandal, S. N.; Das, S. K., (2008). Adsorption, kinetics and equilibrium studies on removal of $\mathrm{Cr}$ (VI) from aqueous solutions using different low-cost adsorbents., Chem. Eng. J., 137 (3), 529-541 (13 pages).

Boddu, V. M.; Abburi, K.; Talbott, J. L.; Smith, E. D., (2003). Removal of hexavalent chromium from wastewater using a new composite chitosan biosorbent. Environ. Sci. Tech., 37 (19), 4449- 4456 (8 pages).

Chen, J. P.; Hong, L.; Wu, S. N.; Wang, L., (2002). Elucidation of interaction between metal ions and $\mathrm{Cu}$ alginate-based ion-exchange resin by spectroscopic analysis and modeling simulation. Langmuir, 18 (24), 9413-9421 (9 pages). 
Chopra, R. N.; Nayer S. L.; Chopra, I. C., (1956). Glossary of Indian medicinal plants, CSIR, New Delhi, p. 31.

CPCB, (1998). Pollution control acts, rules and notification issued hereunder. 311-312, New Delhi: Central Pollution Control Board, Ministry of Environment and Forests, 501. Cruz, C. C. V.; Da Costa, A. C. A.; Henriques, C. A.; Luna, A. S., (2004). Kinetic modeling and equilibrium studies during cadmium biosorption by dead Sargassum sp. Biomass., Bioresour. Tech., 91 (3), 249-257 (9 pages).

Dakiky, M.; Khamis, M.; Manassra, A.; Mereb, M., (2002). Selective adsorption of chromium (VI) in industrial wastewater using low-cost abundantly available adsorbents. Adv. Environ. Res., 6 (4), 533-540 (8 pages).

Das, D. D.; Mahapatra, R.; Pradhan, J.; Das, S. N.; Thakur, R. S., (2000). Removal of $\mathrm{Cr}$ (VI) from aqueous solution using activated cow dung carbon. J. Colloid Interf. Sci., 232 (2), 235-240 (6 pages).

Dokken, K.; Gamez, G.; Herrera, I.; Tiemann, K.; Pingitore, N. E.; Chianelli, R. R.; Gardea-Torresdey, J. L., (1999). Characterization of chromium (VI) bioreduction and chromium (III) binding to alfalfa biomass. In Proceedings of the 1999 Conference on Hazardous Waste Research, Snowbird, Utah, 101-113.

Donmez, D.; Aksu, Z., (2002). Removal of chromium (VI) from saline wastewaters by Dunaliella species. Proc. Biochem., 38 (5), 751-762 (12 pages).

Freundlich, H. M. F., (1906). Uber die adsorption in lösungen, Zeitschrift für Physikalische Chemie (Leipzig) 57A, 385-470.

Garg, V. K.; Gupta, R.; Kumar, R.; Gupta, R. K.; (2004). Adsorption of chromium from aqueous solution on treated sawdust. Bioresour. Tech., 92 (1), 79-81 (10 pages)..

Hamadi, N. K.; Chen, X. D.; Farid, M. M.; Lu, M. G. Q., (2001). Adsorption kinetics for the removal of chromium (VI) from aqueous solution by adsorbents derived from used tyres and sawdust. Chem. Eng. J., 83 (2), 95-105 (11 pages).

Ho, Y. S.; G. Mckay., (1998). Sorption of dye from aqueous solution by peat. Chem. Eng. J., 70 (2), 115-124 (10 pages).

Ho,Y. S.; G. Mckay., (1999). Sorption of lead (II) ions on peat. Water Res., 33 (2), 578-584 (7 pages).

Karthikeyan, T.; Rajgopal, S.; Miranda, L. R., (2005). Chromium (VI) adsorption from aqueous solution by Hevea Brasilinesis sawdust activated carbon. J. Hazard. Mater., B124 (1-3), 192-199 (8 pages).

Lagergren, S., (1898). About the theory of so-called adsorption of solution substances. Handlinge, 24 (4), 147-156 (10 pages).

Langmuir., (1918). The adsorption of gases on plane surfaces of glass, mica and platinum. J. Am. Chem. Soc., 40 (9), 1361-1403 (43 pages).

Loukidou, M. X.; Zouboulis, A. I.; Karapantsios, T. D.; Matis, K. A., (2004). Equilibrium and kinetic modeling of chromium
(VI) biosorption by Aeromonas caviae., Colloid Surface A., 242 (1-3), 93-104 (12 pages).

Mahvi, A. H., (2008) Application of agricultural fibers in pollution removal from aqueous solution. Int. J. Environ. Sci. Tech., 5 (2), 275-285 (11 pages).

Mohan, D.; Singh, K. P.; Singh, V. K., (2005). Removal of hexavalent chromium from aqueous solutions using lowcost activated carbons derived from agricultural waste materials and activated carbon fabric cloth. Ind. Eng. Chem. Res., 44 (4), 1027-1042 (16 pages).

Nameni, M.; Alavi Moghadam, M. R.; Arami, M., (2008) Adsorption of hexavalent chromium from aqueous solutions by wheat bran. Int. J. Environ. Sci. Tech., 5 (2), 161-168 (8 pages).

Oliveira, E. A.; Montanher, S. F.; Andrade, A. D.; Nóbrega, J. A.; Rollemberg, M. C., (2005). Equilubrium studies for the sorption of crmium and nickel from aqueous solutions using raw rice bran. Proc. Biochem., 40, 3485-3490 (6 pages).

Popuri, S. R.; Jammala, A.; Reddy, K. V. N. S.; Abburi, K., (2007). Biosorption of hexavalent chromium using Tamarind (Tamarindus indica) fruit shell-a comparative study. Electron. J. Biotech., 10 (3), 358-367 (10 pages).

Redlich, O.; Peterson, D. L., (1959). A useful adsorption isotherm. J. Hazard. Mater., 63 (6), 1024-1027 (4 pages).

Selvi, K.; Pattabhi, S.; Kadirvelu. K., (2001). Removal of Cr (VI) from aqueous solution by adsorption on to activated carbon. Bioresour. Tech., 80 (1), 87-89 (3 pages).

Shah, B. A.; Shah, A. V.; Singh, R. R., (2009). Sorption isotherms and kinetics of chromium uptake from wastewater using natural sorbent material. Int. J. Environ. Sci. Tech., 6 (1), 77-90 (14 pages).

Shrestha, R.; Fischer, R.; Sillanpaa, M., (2007) Investigations on different positions of electrodes and their effects on the distribution of $\mathrm{Cr}$ at the water sediment interface. Int. J. Environ. Sci. Tech., 4 (4), 413-420 (8 pages).

Sips, R., (1948). On the structure of a catalyst surface. J. Phys. Chem., 16 (5), 490-495 (6 pages).

Venkateswaran, P.; Vellaichamy, S.; Palanivelu K., (2007) Speciation of heavy metals in electroplating industry sludge and wastewater residue using inductively coupled plasma. Int. J. Environ. Sci. Tech., 4 (4), 497-504 (8 pages).

Wang, X. S.; Li, Z. Z.; Sun, C., (2008). Removal of Cr (VI) from aqueous solutions by low-cost biosorbents: marine macroalgae and agricultural by products. J. Hazard. Mater., 153 (3), 1176-1184 (9 pages).

Zvinowanda, C. M.; Okonkwo, J. O.; Shabalala, P. N.; Agyei, N. M., (2009) A novel adsorbent for heavy metal remediation in aqueous Environments. Int. J. Environ. Sci. Tech., 6 (3), 425-434 (10 pages).

\section{AUTHOR (S) BIOSKETCHES}

Vinodhini, V., Ph.D. Candidate, Environmental Biotechnology Division, School of Biosciences and Technology at VIT University, Vellore, State- Tamil Nadu, India. Email: vinodhini05@yahoo.co.in

Das, N., Ph.D., Full Professor, Environmental Biotechnology Division, School of Biosciences and Technology at VIT University, Vellore, State- Tamil Nadu, India. Email: nilanjana00@lycos.com

How to cite this article: (Harvard style)

Vinodhini, V.; Das, N., (2010). Relevant approach to assess the performance of sawdust as adsorbent of chromium (VI) ions from aqueous solutions. Int. J. Environ. Sci. Tech., 7 (1), 85-92. 